\title{
Efficacy of sanitation and sanitary factors against the German cockroach (Blattella germanica) infestation and effectiveness of educational programs on sanitation in Iran
}

Gholam Hossein Shahrakia, ${ }^{\mathrm{a},}$, Hafidzi Mohd Noor ${ }^{\mathrm{a}}$; Javad Rafinejad ${ }^{\mathrm{c}}$, Mohd KhadriShahar ${ }^{\mathrm{d}}$, YusofBin Ibrahim ${ }^{\mathrm{e}}$ a Department of Plant Protection, Faculty of Agriculture, University Putra Malaysia, UPM Serdang, Selangor 43400, Malaysia. ${ }^{b}$ Department of Public Health, Faculty of Health Sciences, Yasuj University of Medical Sciences, Yasuj 75918, Iran. ${ }^{d}$ Department of Medical Entomology, School of Public Health \& Institute of Public Health Researches, Tehran University of Medical Sciences, Tehran 14147, Iran. 'Department of Plant Protection, Faculty of Agriculture, Universiti Pendidikan Sultan Idris, Tanjong Malim, Perak 35900, Malaysia. ${ }^{e}$ Institute of Medical Research, Kuala Lumpur 50588, Malaysia

\begin{abstract}
Background: Sanitation and educational programmes as tactics of the biorational control programme to affect bait performance against German cockroaches have been reported, but these are limited to discussion on the effect of these factors alone.

Objective: Investigate the effectiveness of sanitation and related factors on German cockroaches (Blattella germanica) in Iran.

Methods: Sticky traps were used to monitor cockroach infestations at three residential buildings comprising of 150 apartment units in the southwest part of Iran. Educational programmes using pamphlets, posters, and lectures to describe the importance of sanitation, exclusion, and low toxic control in biorational control approach was performed in the intervention groups of the surveyed residential buildings. The cockroach index and sanitation rate tables were tools to evaluate the infestation and sanitation. A questionnaire was distributed to collect information on unsanitary factors and occupants' attitudes towards sanitation.

Results: There was a significant correlation between infestation and poor sanitation. Furthermore, there was significant correlation between infestation and sanitation in a biorational system. The effectiveness of a comprehensive educational program on the improvement of unsanitary factors such as "dirty and cluttered", "unwashed dishes left at night" and "leftover foods exposed at places" or "food debris" was significant as it reduced upon cockroach infestation. Other relevant effects were also taken into consideration.

Conclusion: Sanitation has positive impact in reduction of German cockroach infestation.
\end{abstract}

Keywords: Biorational control, education, German cockroach, infestation rate, sanitation rate, unsanitary factors

There are over 3,500 species of cockroaches worldwide, but only a few species are commonly associated with humans. Three domiciliary species of importance are the German cockroach (Blattella germanica), the American cockroach (Periplaneta

Correspondence to: Gholam Hossein Shahraki, Department of Plant Protection, Faculty of Agriculture, University Putra Malaysia, UPM Serdang, Selangor 43400, Malaysia.

E-mail:shahraki.gh@gmail.com. americana), and the Oriental cockroach (Blatta orientalis) [1]. The German cockroach is the most common indoor species, especially in housing areas $[2,3]$. A potential mechanical vector of human diseases, many pathogenic organisms have been associated with cockroaches. These include poliomyelitis viruses, bacteria, fungi, protozoa, and helminthes [4-7]. Pai et al. [8] reported cockroaches as potential vectors of nosocomial infections. 
Bacteria with antibiotic resistance have been isolated from household cockroaches [9, 10]. In addition, cockroaches might cause household allergy and entomophobia. It has been shown that the incidence of asthma and allergies is greater in people continually exposed to cockroach infestations $[4,11]$. Sarinho et al. [12] showed that exposure to cockroaches by children can be considered a risk factor for asthma. Cockroach infestations in households can serve as psychological stressors to the residents [13]. Cockroaches secrete smelly oils that are offensive and can ruin food. They also impart odors to dishes that look clean [14].

In pest management, sanitation reflects the availability of water, food, and harborage in a particular environment. Thus, removing the three resources can regulate cockroach numbers [15]. Water is the most crucial factor determining the survival of the German cockroaches. According to the study by Stephan [16], harborage removal is the most disruptive. Sanitation was also reported as a major affecting factor determining the bait performance against German cockroaches [17. 18]. Lee CY and Lee LC [19] reported that the field performance of insecticidal baits on the American cockroach was improved by a better sanitation. However, there was no direct relationship between sanitation rate and the level of infestations. Other studies proved that the availability of food and water [20] and poor sanitation [21] would exacerbate cockroach infestations.

Many researchers have pointed out effectiveness of educational programs on attitude of building occupants toward sanitation $[22,23]$. Biorational approach to pest control means having a minimal disruptive effect on the environment and its inhabitants [24]. The strategy of biorational control approach is based on the integration of multiple control strategies. This includes repeated monitoring, sanitation, educational program, and the limited use of pesticides [25-27]. The present study dealt with determining the effectiveness of sanitation in a biorational system on the infestation of the German cockroach in Iran.

\section{Materials and methods}

Sticky traps $\left(\right.$ Ridsect ${ }^{\circledR}$, Sara Lee Malaysia, Petaling Jaya) were used as the tools for monitoring cockroach populations in the infested units. The trap catch data was recorded weekly over a seven-day trapping period. The study locations comprised of two student dormitories and a residential building in the southwestern area of Iran. About 25 apartments of the residential building and 125 dormitory units (girls and boys dormitories) were monitored for cockroaches.

Cockroach trap counts were recorded weekly per trap per unit at all study locations. This was defined as the cockroach infestation rate. To evaluate the intensity of infestation (categorized), the cockroach index table was determined for the surveyed residential units, as shown in Table 1.

To assign rates and to estimate the degree of sanitation of the surveyed units, a sanitation-rating table was designed and modified from Wang and Bennett [23], as shown in Table 2.

After assessing the extent of clutter, food, and debris of these places and assigning a rate for cockroach based on Table 2, the sums of these for each corresponding place was recorded as the sanitation rates. The sanitation rates before and after the educational programs was imputed. A comparison of these sanitation rates and infestation rates at the same places and between pre- and post-educational programs were used to establish the relationship between sanitation and cockroach infestation, and the effectiveness of the educational programs on sanitation at the intervention units.

Table 1. Cockroach index.

\begin{tabular}{cl}
\hline $\begin{array}{c}\text { Number of captured cockroaches } \\
\text { per trap per unit }\end{array}$ & Cockroach Index \\
\hline $0 \leq x<1$ & Clean \\
$1 \leq x<3$ & Low \\
$3 \leq x<8$ & Moderate \\
$8 \leq x<26$ & High \\
$26 \leq x<50$ & Very high \\
$x \geq 50$ & Abundant \\
\hline
\end{tabular}


Table 2. Scales used to rate the degree of sanitation (Modified from [23]).

\begin{tabular}{|c|c|c|c|c|}
\hline Rating & $\begin{array}{l}\text { General } \\
\text { condition }\end{array}$ & $\begin{array}{l}\text { Amount of } \\
\text { clutter } \\
\text { dinner area }\end{array}$ & $\begin{array}{l}\text { Amount of trash } \\
\text { on floor }\end{array}$ & $\begin{array}{l}\text { Amount of food } \\
\text { on floor and }\end{array}$ \\
\hline 1 to 6 & $\begin{array}{l}\text { Clean }=1-2 \\
\text { Pretty clean }=3 \\
\text { Dirty }=4-5 \\
\text { Severely dirty }=6\end{array}$ & $\begin{array}{l}\text { Few }=1 \\
\text { Many }=2\end{array}$ & $\begin{array}{l}\text { None }=0 \\
\text { Some }=1 \\
\text { Many }=2\end{array}$ & $\begin{array}{l}\text { None }=0 \\
\text { Some }=1 \\
\text { Many }=2\end{array}$ \\
\hline \multicolumn{2}{|c|}{ Description of module } & $\begin{array}{l}\text { Many = More than } \\
\text { one observable } \\
\text { clutter }\end{array}$ & $\begin{array}{l}\text { Some }=\text { Just } \\
\text { observable after } \\
\text { looking for } \\
\text { Many = visible } \\
\text { without any } \\
\text { searching }\end{array}$ & $\begin{array}{l}\text { Some }=\text { Visible after } \\
\text { exact investigation } \\
\text { Many= Can see them } \\
\text { several points obviously }\end{array}$ \\
\hline
\end{tabular}

Pamphlets and posters were furnished and distributed, while face-to-face educational interactions and lectures were given and provided for the occupants to support the educational programs as the integral part of the biorational system. A lecture for the students in the intervention sites of the girls' dormitory had also been given. They were students of science departments and in the age group of 18 to 25 years. The importance of sanitation, exclusion, and low-toxic control by gel bait for cockroach control was emphasized. The occupants for other intervention sites were given face-to-face interactions to provide them with the needed guidance on biorational control. Posters and pamphlets were distributed to all occupants in the intervention sites. For the educational programs, emphasis was given on the importance of sanitation. Removing food debris and clutters, immediately emptying indoor trash containers, using plastic bag liners, keeping the lid on for trash containers, washing dirty dishes immediately before retiring, was advised to the occupants during the educational program. To evaluate the effectiveness of the educational programs, the infested unit sites were randomly selected for educational intervention and control treatments.

Questionnaires were distributed among occupants in 88 surveyed units to gather information on unsanitary factors and occupants' attitudes towards sanitation in the study locations. Data was analyzed using Spearman's correlation coefficient, Wilcoxon Signed Ranks test, and Mann-Whitney test, with the help of the SPSS15 software.

\section{Results}

Out of 53, 72, and 25 surveyed units of girls and boys dormitories and residential building, 74 , 74 and $60 \%$ of each units were infested with cockroaches, respectively. Identified cockroaches are shown in Fig. 1.

The German cockroaches (Blattella germanica) were the most abundant (99.2\%), comprising all of the trapped cockroaches (the American cockroach (Periplaneta americana), $0.6 \%$, the Turkestan cockroach (Blatta lateralis), $0.2 \%$; and the Oriental cockroach (Blatta orientalis), 0.02\%).

The correlation coefficient between the sanitation rates and infestation rates (converted for the cockroach infested units before educational programs at the residential buildings) showed that there was a significant positive relationship $(n=23$, Spearman correlation coefficient $\left.r_{s}=0.445, p<0.05\right)$ between sanitation rate and intensity of infestation (according to the cockroach index) at the surveyed units (the girls' dormitory) before treatment. The same result was achieved for the residential building $(n=11$, $r_{s}=0.636, p<0.05$ ). For the boys' dormitory, the correlation was not significant $\left(n=19, r_{s}=0.36, p>0.05\right)$.

The sanitation rate significantly improved (from median 4 to 1 ) after several educational programs were conducted $\left(\mathrm{z}=-1.799, \mathrm{p}_{\text {(1-tailed) }}=0.036\right)$. This was further substantiated by the control group, whereby it did not show significant change after this duration (median $=2.5$ $\& 1.5$, z-value by Wilcoxon signed ranks test $\mathrm{z}=-1.59$, $\mathrm{p}=0.112$ ). 


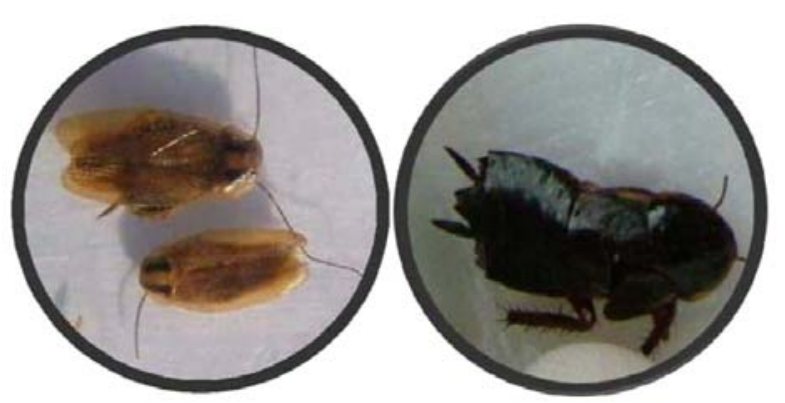

Left: Blattella germanica; Right: Blatta orientalis;

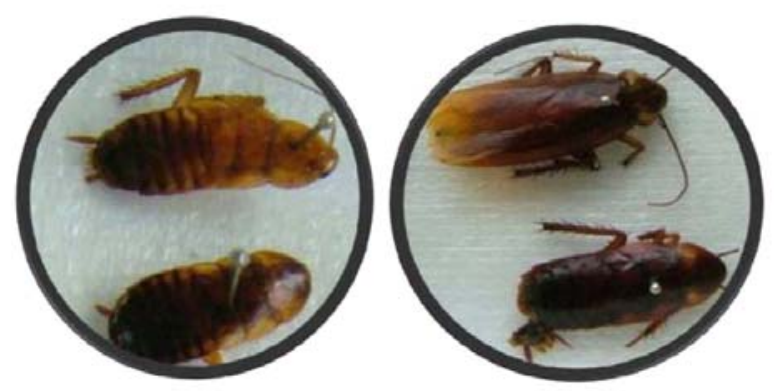

Left: Blatta lateralis; Right: Periplaneta americana

Fig. 1 Identified cockroaches at selected residential buildings located in the south west part of Iran.

The sanitation rates after educational program was given improved (from median 2 to 1.5 for education versus median 1 to 2 for control) for the residential building. However, this difference was not significant $(\mathrm{z}=-1.186, \mathrm{p}=0.236)$. There was no significant difference for sanitation rates (from median 3 to 3 ) at the boys' dormitory $(\mathrm{z}=-0.44, \mathrm{p}=0.66)$. As shown in Table 3, the difference between the two groups (education and control) was not significant.
Correlation between unsanitary factors related to food, water, and harborage (for cockroach survival), and cockroach infestation for 88 surveyed units and 19 dormitory kitchens were shown in Table 4. Table 5 shows the details whether hand brooms to clean houses is used or vacuum is not used at all. Table $\mathbf{6}$ shows the details of using plastic bag linings for trash containers.

Table 3. Average number of sanitation rates pre and post educational program for surveyed units of the girls' dormitory.

\begin{tabular}{|c|c|c|c|c|c|c|}
\hline \multirow[t]{2}{*}{ Treatments } & \multicolumn{3}{|c|}{ Pre-treatment } & \multicolumn{3}{|c|}{ Post-treatment } \\
\hline & $\begin{array}{c}\text { Girls' } \\
\text { dormitory }\end{array}$ & $\begin{array}{c}\text { Boys' } \\
\text { dormitory }\end{array}$ & $\begin{array}{c}\text { Residential } \\
\text { building }\end{array}$ & $\begin{array}{c}\text { Girls' } \\
\text { dormitory }\end{array}$ & $\begin{array}{c}\text { Boys' } \\
\text { dormitory }\end{array}$ & $\begin{array}{c}\text { Residential } \\
\text { building }\end{array}$ \\
\hline Education & $\begin{array}{c}3.64 \\
(M d n=4)\end{array}$ & $\begin{array}{c}2.67 \\
(\mathrm{Mdn}=3)\end{array}$ & $\begin{array}{c}1.67 \\
(\mathrm{Mdn}=2)\end{array}$ & $\begin{array}{c}2.18 \\
(\mathrm{Mdn}=1)\end{array}$ & $\begin{array}{c}2.89 \\
(\mathrm{Mdn}=3)\end{array}$ & $\begin{array}{c}1.67 \\
(\mathrm{Mdn}=1.5)\end{array}$ \\
\hline Control & $\begin{array}{c}2.92 \\
(\mathrm{Mdn}=2.5)\end{array}$ & $\begin{array}{c}2.1 \\
(\mathrm{Mdn}=2)\end{array}$ & $\begin{array}{c}1.6 \\
(\mathrm{Mdn}=1)\end{array}$ & $\begin{array}{c}2.00 \\
(\mathrm{Mdn}=2)\end{array}$ & $\begin{array}{c}2.7 \\
(\mathrm{Mdn}=2.5)\end{array}$ & $\begin{array}{c}2.4 \\
(\mathrm{Mdn}=2)\end{array}$ \\
\hline
\end{tabular}

$\mathrm{Mdn}=$ median. Means within column are not significantly different at $\mathrm{p}=0.05$ by Mann-Whitney test. 
Table 4. Percentage frequency of sanitary and unsanitary factors at cockroach infested units (e" low) and clean level units (according to Cockroach Index Table) for 88 units and 19 kitchens of dormitories.

\begin{tabular}{|c|c|c|c|}
\hline \multirow{2}{*}{$\begin{array}{l}\text { Factors } \\
\text { (related to food, water and harbourage) }\end{array}$} & \multicolumn{2}{|c|}{$\begin{array}{l}\text { Percentage frequency of } \\
\text { unsanitary factors }\end{array}$} & \multirow[t]{2}{*}{ Correlation } \\
\hline & $\begin{array}{l}\text { Infested } \\
\text { units }(\%)\end{array}$ & $\begin{array}{l}\text { Clean level units } \\
(\%)\end{array}$ & \\
\hline Using hand brooms to clean houses & 100 & 97 & $r_{s}=0.117, p>0.05$ \\
\hline Do not vacuum at all & 74 & 69 & $r_{s}=0.041, p>0.05$ \\
\hline Using plastic bag linings for trash containers & 74 & 75 & $\mathrm{r}_{\mathrm{s}}^{\mathrm{s}}=-0.011, \mathrm{p}>0.05$ \\
\hline Tie-up the plastic bags before dumping them & 65 & 72 & $\mathrm{r}_{\mathrm{s}}=-0.078, \mathrm{p}>0.05$ \\
\hline Empty trash containers occasionally & 10 & 5 & $\mathrm{r}_{\mathrm{s}}=0.112, \mathrm{p}>0.05$ \\
\hline Trash containers without lids (for kitchens) & 80 & 75 & $\mathrm{r}_{\mathrm{s}}=-0.05, \mathrm{p}>0.05$ \\
\hline \multicolumn{4}{|l|}{ Left foods, which were not eaten and exposed on the } \\
\hline table before retiring at night & 18 & 3 & $\mathrm{r}_{\mathrm{s}}=-0.237, \mathrm{p}<0.05$ \\
\hline Food debris on the floor (for kitchens) & 80 & 25 & $\mathrm{r}_{\mathrm{s}}=-0.482, \mathrm{p}<0.05$ \\
\hline Unwashed dishes left overnight & 88 & 47 & $\begin{array}{l}\text { at the girls dormitory, } \\
r_{s}=-0.433, p<0.05\end{array}$ \\
\hline Leaking in the plumbing facilities more than 7 days & 69 & 67 & $\mathrm{r}_{\mathrm{s}}=0.016, \mathrm{p}>0.05$ \\
\hline Accumulated water on the floor of the kitchens & 27 & 0 & $\mathrm{r}_{\mathrm{s}}=0.267, \mathrm{p}>0.05$ \\
\hline Dirty and cluttered & 23 & 10 & $\begin{array}{l}\text { at the girls dormitory, } \\
r_{s}=0.315, p<0.05\end{array}$ \\
\hline Clutter with boxes, papers, books and wetly clout & 48 & 41 & $r_{s}=0.067, p>0.05$ \\
\hline Musty wooden equipment & 46 & 31 & $\mathrm{r}_{\mathrm{s}}=0.151, \mathrm{p}>0.05$ \\
\hline Do not clean the spaces under Sedentary furniture & 79 & 68 & $r_{\mathrm{s}}=-0.124, \mathrm{p}>0.05$ \\
\hline
\end{tabular}

Table 5. Situation of cleanliness and clutter of the floors at the study sites.

\begin{tabular}{|c|c|c|c|c|c|c|}
\hline \multirow[b]{2}{*}{ Location } & \multirow[b]{2}{*}{$\begin{array}{l}\text { Cockroach } \\
\text { infestation }\end{array}$} & \multirow[b]{2}{*}{$\begin{array}{l}\text { Type of } \\
\text { data }\end{array}$} & \multicolumn{3}{|c|}{$\begin{array}{l}\text { Situation of floor for surveyed room } \\
\text { or sitting room }\end{array}$} & \multirow[b]{2}{*}{ Total } \\
\hline & & & $\begin{array}{l}\text { Clean and } \\
\text { regular }\end{array}$ & $\begin{array}{l}\text { Clean \& } \\
\text { clutter }\end{array}$ & $\begin{array}{l}\text { Dirty \& } \\
\text { clutter }\end{array}$ & \\
\hline \multirow[t]{6}{*}{ All dormitories } & \multirow{2}{*}{$\begin{array}{l}\text { Clean level of } \\
\text { infestation }\end{array}$} & no. of units & 33 & 1 & 4 & 38 \\
\hline & & $\%$ & $86.8 \%$ & $2.6 \%$ & $10.5 \%$ & $100 \%$ \\
\hline & \multirow{2}{*}{$\begin{array}{l}\text { Infested with } \\
\text { cockroach }\end{array}$} & no. of units & 32 & 1 & 10 & 43 \\
\hline & & $\%$ & $74.4 \%$ & $2.3 \%$ & $23.3 \%$ & $100 \%$ \\
\hline & \multirow[t]{2}{*}{ Total } & no. of units & 65 & 2 & 14 & 81 \\
\hline & & $\%$ & $80.2 \%$ & $2.5 \%$ & $17.3 \%$ & $100 \%$ \\
\hline \multirow[t]{6}{*}{ Girls dormitory } & \multirow{2}{*}{$\begin{array}{l}\text { Clean level of } \\
\text { infestation }\end{array}$} & no. of units & 18 & 0 & 0 & 18 \\
\hline & & $\%$ & $100 \%$ & $0 \%$ & $0 \%$ & $100 \%$ \\
\hline & \multirow{2}{*}{$\begin{array}{l}\text { Infested with } \\
\text { cockroach }\end{array}$} & no. of units & 14 & 0 & 3 & 17 \\
\hline & & $\%$ & $82.4 \%$ & $0 \%$ & $17.6 \%$ & $17.6 \%$ \\
\hline & \multirow[t]{2}{*}{ Total } & no. of units & 32 & 0 & 3 & 35 \\
\hline & & $\%$ & $91.4 \%$ & $0 \%$ & $8.6 \%$ & $100 \%$ \\
\hline
\end{tabular}


Table 6. Percentage frequency of vacuuming for surveyed units of the dormitories.

\begin{tabular}{|c|c|c|c|c|c|c|}
\hline \multirow[b]{2}{*}{$\begin{array}{l}\text { Cockroach } \\
\text { infestation }\end{array}$} & \multirow[b]{2}{*}{ Type of data } & \multicolumn{4}{|c|}{ Frequency of vacuuming } & \multirow[b]{2}{*}{ Total } \\
\hline & & $\begin{array}{l}\text { Every } \\
\text { day }\end{array}$ & $\begin{array}{l}\text { Alternate } \\
\text { days }\end{array}$ & $\begin{array}{l}\text { More than } \\
2 \text { days alternate }\end{array}$ & Don't use & \\
\hline Clean level of & no. of units & 4 & 1 & 7 & 27 & 39 \\
\hline infestation & $\%$ & $10.3 \%$ & $2.6 \%$ & $17.9 \%$ & $69.2 \%$ & $100 \%$ \\
\hline Infested with & no. of units & 4 & 2 & 5 & 31 & 42 \\
\hline cockroach & $\%$ & $9.5 \%$ & $4.8 \%$ & $11.9 \%$ & $73.8 \%$ & $100 \%$ \\
\hline Total & no. of units & 8 & 3 & 12 & 58 & 81 \\
\hline & $\%$ & $9.9 \%$ & $3.7 \%$ & $14.8 \%$ & $71.6 \%$ & $100 \%$ \\
\hline
\end{tabular}

\section{Discussion}

The survey on the girls' dormitory and residential building indicated that there was a significant correlation between sanitation (i.e. high rate) and infestation (i.e. high cockroach index). In other words, poor sanitation was associated with the intensity of cockroach infestation. Schal [21] pointed similar result. In this study, there was a positive relationship between poor sanitation and cockroach infestation at the residential building and girls dormitory, but the boys' dormitory showed different result. Lee and Lee [19] reported that there was no direct relationship between poor sanitation and cockroach infestation. In the "boys dormitory", the bathrooms were located inside the units, while in the "girls dormitory", they were outside the units. This different location might affect the correlation between sanitation and infestation at the girls and boys dormitories.

The effects of unsanitary factors, associated with food such as food debris (for the kitchens), leftover foods exposed on the table, as well as unwashed dishes left overnight, contributed to the higher infestation rates $(p<0.05)$ in this study as well as in the study by Lee et al. [20]. Schal [21] substantiated the positive effects of unsanitary factors, such as dirtiness and clutter on cockroach infestation in this study.

Unsanitary factors associated with water such as "accumulated water on the floor" for the surveyed kitchens and "leaking in the plumbing facilities" also had effect $(p>0.05)$ on cockroach infestation in this study. This result agreed with another study by Stephan et al. [16]. This study showed that increased infestation was contributed by the effects of factors associated with harborage for cockroaches such as "clutter", "lack of cleaning of spaces under sedentary furniture", "musty wooden equipment", "occasionally empty trash containers", "trash containers without lids", "do not use plastic bag lining" and "do no tie-up plastic bags before dumping them". This result agreed with the study by Faith et al. [14]. Moreover, the trash containers could act as a food resource for the cockroaches. The positive correlation between "does not vacuum" and cockroach infestation was established and was substantiated by significant effects of high sanitation rate and "dirtiness and clutter" on infestation in this study and another study [29].

The results for the "girls' dormitory" showed that the educational programs improved the sanitation in the area. Wang and Bennett [23] reported the improvement for sanitation levels in the IPM group after intervention. MacConnell et al. [22] also showed the effectiveness of educational intervention to reduce cockroach allergen.

Educational programs for the "girls dormitory" were comprehensive, including "lectures, face-to-face interaction and distribution of pamphlets, and poster". However, for "residential building" and "boy dormitory", the attention was mostly given on faceto-face interaction, pamphlets and posters. Hence, the comprehensive educational programme for the girls' dormitory was the most effective in improving the attitudes towards sanitation by the occupants.

The field efficacy of poor sanitation (i.e. dirty and severely dirty levels) on cockroach infestation from the survey on sanitation rate and unsanitary factors was revealed. This indicated the importance of sanitation for biorational approach, as stated by Lee and Lee [19], and Wang and Bennett [23].

\section{Conclusion}

The correlation between unsanitary factors and cockroach infestation indicates that in cockroach control management a lot of attention should be given on the improvement of sanitation. The sanitation rate 
was associated with cockroach infestation and educational programs. Improving sanitation is an important step for a successful biorational control strategy.

\section{Acknowledgment}

We would like to thank the academic ViceChancellor of Yasuj University of Medical Sciences for their allowance of the use of the study sites. We acknowledge Prof. Dzolkhifli Omar and Dr. Faizah Abood for their helpful suggestions. The authors have no conflict of interest to declare.

\section{References}

1. Goddard J. Physician's guide to arthropods of medical importance. Boca Raton:CRC Press, 2003.p. 444.

2. Wang C, Abdul El-Nour M, Bennett GW. Survey of pest infestation, asthma, and allergy in low income housing. J Community Health. 2008; 33:31-9.

3. Whyatt RM, Camann DE, Kinney PL, Reyes A, Ramirez $\mathrm{J}$, Dietrich J, et al. Residential pesticide use during pregnancy among a cohort of urban minority women. Environm Health Perspect. 2002; 110:79-84.

4. Baumholtz MA, Parish LC, Witkowski JA, Nutting WB. The medical importance of cockroaches. Int J Dermatol. 2008;36:90-6.

5. Saichua P, Pinmai K, Somrithipol S, Tor-Udom S. Isolation of medically important fungi from cockroaches trapped at Thammasat Chalermprakiat Hospital. Thammasat Med J. 2008; 8:345-51.

6. Fathpour H, Emtiazi G, Ghasemi E. Cockroaches as reservoirs and vectors of drug resistant Salmonella spp. Iran Biomed J. 2003; 7:35-8.

7. Tatfeng YM, Usuanlel MU, Orukpe A, Digban AK, Okodua M, Oviasogie F, et al. Mechanical transmission of pathogenic organisms: the role of cockroaches. J Vect Born Dis 2005; 42:129-34.

8. Pai HH, Chen WC, Peng CF. Cockroaches as potential vectors of nosocomial infections. Infect Control Hospital Epidemiol. 2004; 25:979-84.

9. Pai HH, Chen WC, Peng CF. Isolation of bacteria with antibiotic resistance from household cockroaches (Periplaneta americana and Blattella germanica). Acta Tropica. 2005; 93:259-65.

10. Devi SJN, Murray CJ. Cockroaches (Blatta and Periplaneta species) as reservoirs of drug-resistant salmonellas. Epidemiol Infect. 1991; 107:357-61.

11. Nalyanya G, Gore GH, Linker HM, Schal C. German Cockroach allergen levels in North Carolina Schools: comparison of integrated pest management and conventional Cockroach control. J Med Entomol. 2009; 46:420-7.

12. Sarinho E, Schor D, Veloso MA, Rizzo JA. There are more asthmatics in homes with high cockroach infestation. Braz J Med Biol Res. 2004; 37:503-10.

13. Lee CY. Medical importance of domiciliary cockroaches. Singap Microbiologist. 1997; 11:14-17.

14. Faith MO, Arthur GA, Eric PB. 19974 April. IPM Tactics for Cockroach Control. Available from: http:// www.aces.edu/pubs/docs/A/ANR-1016/. Accessed 4 April 2006.

15. Bonnefoy X, Kampen H, Sweeney K. Public health significance of urban pests. Copenhagen:WHO Europe, 2008. p. 569

16. Stephan RE. Factors influencing the movement German cockroaches [Dissertation]. Purdue Purdue University; 1984.p. 85 .

17. Christensen C. Cockroach baits. Pest Control Technol. 1991; 19:45-51.

18. Noureldin EM, Farrag HA. The role of sanitation in the control of German cockroach (Blattella germanica L.). Biosci Biotechn Res Asia. 2008; 5:525-36.

19. Lee CY, Lee LC. Diversity of cockroach species and effect of sanitation on level of cockroach infestation in residential premises. Trop Biomed. 2000; 17:39-43.

20. Lee CY, Heng CY. Effects of food and water deprivation on nymphal development, adult fecundity and insecticide susceptibility in German cockroaches, Blattella germanica (L.). Trop Biomed. 2000; 17:27-34.

21. Schal C. Relation among efficacy of insecticides, resistance levels, and sanitation in the control of the German cockroach (Dictyoptera: Blattellidae). J Econom Entomol. 1988; 81:536-44.

22. McConnell R, Milam J, Richardson J, Galvan J, Jones $\mathrm{C}$, Thorne $\mathrm{P}$, et al. Educational intervention to control cockroach allergen exposure in the homes of hispanic children in Los Angeles: results of the La Casa study. Clin Exper Allergy. 2005; 35:426-33.

23. Wang C, Bennett GW. Comparative study of integrated Pest management and baiting for German cockroach management in public housing. J Econom Entomol. 2006; 99:879-85.

24. Ishaaya I, Horowitz RA, Horowitz AR. Biorational control of arthropod Pests: application and resistance management. New York:Springer, 2009. p. 408.

25. Lucas JR, Invest JF. Factors involved in the successful use of hydramethylnon baits in household and industrial pest control. In: Wildey KB, Robinson WH, editors. First International Conference on Insect Pests in the Urban Environment. Cambridge:BPCC 
Wheatons Exeter, 1993.p. 99-106.

26. Greene A, Breisch NL. Measuring integrated pest management programs for public buildings. J Econom Entomol. 2002; 95:1-13.

27. Brenner BL, Markowitz S, Rivera M, Romero H, Weeks $\mathrm{M}$, Sanchez E, et al. Integrated Pest management in an urban community: a successful partnership for prevention. Environm Health Perspect. 2003; 111: 1647-53.
28. Lee CY, Lee LC. Influence of sanitary conditions on the field performance of chlorpyrifos-based baits against American cockroaches, Periplaneta americana (L.) (Dictyoptera: Blattidae). J Vector Ecology. 2000; 25:218-21.

29. Kaakeh W, Bennett GW. Evaluation of trapping and vacuuming compared with low-impact insecticide tactics for managing German cockroaches in residences. J Econom Entomol. 1997; 90:976-82. 